\title{
EFFECT OF PERSONAL FACTORS, FAMILY SUPPORT, POCKET MONEY, AND PEER GROUP, ON SMOKING BEHAVIOR IN ADOLESCENTS IN SURAKARTA, CENTRAL JAVA
}

\author{
Ardiansyah Pandayu ${ }^{1)}$, Bhisma Murti ${ }^{1}$, Pawito $^{2)}$ \\ 1)Masters Program in Public Health, Sebelas Maret University \\ 2)Faculty of Social and Political Sciences, Sebelas Maret University
}

\begin{abstract}
Background: Indonesia is the third largest country with current smokers in the world, including young smokers. It is widely known that smoking is hazardous to health and detrimental to economy. Surakarta is one of the major cities in Central Java where the prevalence of current smokers has been increasing among adolescents. This study aimed to determine the effect of personal factors, family support, pocket money, and peer group, on smoking behavior
\end{abstract} in adolescents in Surakarta, Central Java.

Subjects and Method: This was an analytic observational study using cross-sectional design. This study was carried out in 5 sub-districts in Surakarta, Central java, from February to March 2017. A sample of 50 adolescent smokers and 150 adolescent non-smokers was selected for this study by fixed disease sampling. The dependent variable was current smoking status. The independent variables were cigarette availability, peer-group, family support, pocket money, cigarette advertisement, attitude toward smoking, subjective norm, perceived preventive behavioral control, and intention. The data were collected by a set of questionnaire. The data were analyzed by path analysis.

Results: Smoking behavior was affected by strong intention $(b=3.7 ; 95 \% \mathrm{CI}=2.5$ to $4.9 ; \mathrm{p}<0.001)$, and weak perceived behavioral control $(\mathrm{b}=3.1 ; 95 \% \mathrm{CI}=1.7$ to $4.5 ; \mathrm{p}<0.001)$. Intention to smoke was affected by weak perceived preventive behavioral control $(b=2.1 ; 95 \% \mathrm{CI}=1.1$ to $3.2 ; \mathrm{p}<0.001)$, weak preventive subjective norm $(\mathrm{b}=1.8 ; 95 \% \mathrm{CI}=0.7$ to $2.9 ; \mathrm{p}=0.001)$, negative attitude $(\mathrm{b}=1.9 ; 95 \% \mathrm{CI}=0.8$ to $2.9 ; \mathrm{p}<0.001)$, and exposure to cigarette advertisement $(b=1.6 ; 95 \% \mathrm{CI}=0.5$ to $2.6 ; \mathrm{p}=0.004)$. Weak perceived preventive behavioral control was affected by pocket money $\geq R p 10.000(b=$ 1.3; $95 \% \mathrm{CI}=0.5$ to $2.0 ; \mathrm{p}=0.001)$. Weak preventive subjective norm was affected by weak family support $(b=2.1 ; 95 \% \mathrm{CI}=1.3$ to $2.8 ; \mathrm{p}<0.001)$ and smoker peer-group $(b=1.4 ; 95 \% \quad C I=0.6$ to $2.1 ; \mathrm{p}<0.001)$. Cigarette advertisement was affected by cigarette availability $(b=0.7 ; 95 \% \mathrm{CI}=0.1$ to $1.3 ; \mathrm{p}=0.028)$.

Conclusion: Smoking behavior was directly affected by strong intention and weak perceived behavioral control. Smoking behavior was indirectly affected by weak preventive subjective norm, negative attitude, exposure to cigarette advertisement, pocket money $\geq$ Rp 10.000, weak family support, smoker peer-group, and cigarette availability.

Keywords: path analysis, smoking behavior, intention, adolescents

Correspondence: Ardiansyah Pandayu. Masters Program in Public Health, Sebelas Maret University, Jl. Ir. Sutami 36 A, Surakarta 57126, Central Java, Indonesia. Email: ardiansyahpandayuo7@gmail.com.

Mobile: +6287864018631 . 